\title{
ASSESSMENT FEATURES OF THE FISHERIES COMPANIES' FINANCIAL STABILITY IN THE PRIMORSKY REGION, RUSSIA
}

\author{
Konvisarova E.V., Levchenko T.A.*, Candidates of Economic Sciences \\ Kovaleva I.V., Graduate student \\ Vladivostok State University of Economics and Service, Vladivostok, Russia \\ ${ }^{*}$ E-mail: tat levchenko22@mail.ru
}

\begin{abstract}
The relevance of the research is determined by the fact that the fishing industry is one of the leading sectors of the economy of Primorsky Region. Its effective development is an important governmental objective, as it is reflected in the state program "Development of Fishery Complex in Primorsky region for 2013-2020". One of the manifestations of the sustainable functioning of the Fishery Complex is the achieving of a high level of financial stability of organizations in fishing industry. The aim of the research was the developing of recommendations for improving the assessment of financial stability taking into consideration specific characteristics of fishery management organizations.
\end{abstract}

\section{KEY WORDS}

Financial stability, assessment, methodology, fisheries enterprises, integral indicator, Primorsky region.

Issues of assessment of financial stability of the entity was reflected in the works of many scientists-economists, among which there are such as L.T. Gilyarovskaya [3], V.V. Kovalev [4], E. V. Konvisarova [2, 5], M.G. Lapusta [8], A.D. Sheremet [13] and others. The most popular methods of assessing financial stability of the organization are: three-factor model, characterizing the type of financial stability; models based on the calculation of financial ratios; methods and techniques of forecasting of bankruptcy. Based on the content analysis of these techniques, it is possible to highlight their specific drawbacks:

1. There is no single estimated figure, which gives a complex picture of the financial activity of economic entity.

2. Used as one of the main tools of analysis, financial ratios typically do not take into account specific features of the object of analysis, and as a result, their value does not always reflect the real situation in the organization.

3. Most of the existing techniques are used as an information base only for accounting data and do not take into consideration the record of management, which greatly impoverishes the range of the resulting estimates.

4. Assessment of the probability of bankruptcy, to the greatest extent, takes into account the development of the organization at the stage of the decline, but its use is not fully adequate in other phases of the life cycle of a business entity.

These shortcomings require the development of a technique, which could solve at least some of the mentioned problems, in particular, the lack of special accountancy of the specific industry.

For the Far East of Russia and for Primorsky region one of the leading sector traditionally was the fishing industry. The works of O.Y. Vorozhbit [14-16], O.V. Korneyko, A.P. Latkin [6, 7], E.V. Levkina [9], T.A. Levchenko [1, 10] and others are dedicated to the study of aspects of the development of the fisheries companies in Primorsky region, evaluating their financial condition and competitiveness.

However, despite the wide range of researches, the problem of taking into consideration the specific industry features is not sufficiently explored while assessing the financial sustainability of the companies of the fisheries industry. 
Assessment of financial stability is impossible without revealing of general tendencies of industry development. The results of the analysis of economic indicators, using the data of Administration of the Primorsky region [11], are presented in table 1.

Table 1 - Economic indicators of fishery in the Primorsky region in 2014-2016

\begin{tabular}{|l|c|c|c|c|c|}
\hline \multicolumn{1}{|c|}{ Indicator } & 2014 & 2015 & 2016 & $\begin{array}{c}2015 / \\
2014, \%\end{array}$ & $\begin{array}{c}2016 / \\
2015, \%\end{array}$ \\
\hline The catch of fish and non-fish species, thousands tons & 778,0 & 739,3 & 836,9 & 95,0 & 113,2 \\
\hline $\begin{array}{l}\text { The share of fishery sector in the shipment of goods of } \\
\text { own production in industrial enterprises of the region, \% }\end{array}$ & 14,6 & 21,9 & 23,1 & 150,0 & 105,5 \\
\hline $\begin{array}{l}\text { The organizations turnover in fishery and fish-farming, } \\
\text { mln. RUB }\end{array}$ & 29985,7 & 42508,5 & 43613,7 & 141,8 & 102,6 \\
\hline Export, thousands tons & 549,5 & 529,6 & 568,3 & 96,4 & 107,3 \\
\hline The share of exports in total amount of products, \% & 80,5 & 77,5 & 73,2 & 96,3 & 94,5 \\
\hline Export (the cost), mln. dollars USA & 967,9 & 885,2 & 938,7 & 91,5 & 106,0 \\
\hline The number of employed, thousands & 10,4 & 10,4 & 10,6 & 100,0 & 101,1 \\
\hline The average salary for 1 working person, RUB & 37660 & 56729 & 65295 & 150,6 & 115,1 \\
\hline Paid taxes and other obligatory payments, mln. RUB & 1556,8 & 2260,0 & 3187,7 & 145,2 & 141,0 \\
\hline Balanced financial result, mln. RUB & 2732,4 & 9394,3 & 12052,9 & $\begin{array}{c}\text { in } 3,4 \\
\text { times }\end{array}$ & 128,3 \\
\hline The share of profitable enterprises, \% & 71,6 & 91,7 & 90,5 & 128,1 & 98,7 \\
\hline
\end{tabular}

The analysis allowed to make the following conclusions: the total catch of aquatic biological resources and turnover of organizations is increasing; last two years, the share of fishery sector in the shipment of goods of own production in industrial enterprises was increasing on the background of general growth of production volumes, however, this growth in 2016 was slowed down considerably; companies in the industry are focused mainly on foreign trade activities; for 2 years balanced financial result of activity was increased at $4.4 \%$, which led to higher profitability.

The trends were mainly developed on the background of the influence of factors of external environment (direct and indirect) that may affect financial stability. The most significant of them are: peculiarities of consumer demand in the domestic and foreign markets, high risks in the fishery because of existing administrative barriers, the inertia of the production-technological model and not enough rate of productivity growth of the industry, the existence of a "quota rentiers" and the lack of investments.

For more profound conclusions the estimation of the financial stability of specific companies was carried out. The companies were selected on the basis of the rating of the largest organizations of fishery industry in Primorsky region. They are PJSC "Dalryba", PJSC "Nakhodka's Base of Active Sea Fishing" (PJSC "NBAMR"), PJSC "Preobrazhenie's Base of trawling fleet" (PJSC "PBTF"). The evaluation was carried out using the three-factor model, characterizing the type of financial stability, based on the calculation of financial ratios, as well as using methods of bankruptcy forecasting. The results are presented in table 2.

Table 2 - Summary results of financial stability evaluation of companies of fishery industry in the Primorsky region

\begin{tabular}{|c|c|c|c|}
\hline Company & $\begin{array}{c}\text { Three-factor model of financial } \\
\text { sustainability }\end{array}$ & Ratio analysis & $\begin{array}{c}\text { Models, estimated the } \\
\text { probability of } \\
\text { bankruptcy }\end{array}$ \\
\hline $\begin{array}{c}\text { PJSC } \\
\text { "Dalryba" }\end{array}$ & $\begin{array}{c}\text { Financial stability had positive } \\
\text { dynamics, reaching the } \\
\text { absolute values in 2016 }\end{array}$ & $\begin{array}{c}\text { The calculated coefficients had positive } \\
\text { dynamics and they were at the } \\
\text { recommended level }\end{array}$ & $\begin{array}{c}\text { it is impossible to do } \\
\text { unmistakable } \\
\text { conclusion }\end{array}$ \\
\hline $\begin{array}{c}\text { PJSC } \\
\text { "NBAMR" }\end{array}$ & $\begin{array}{c}\text { Financial stability had positive } \\
\text { dynamics, reaching the } \\
\text { absolute values in 2016 }\end{array}$ & $\begin{array}{c}\text { The calculated coefficients had valid } \\
\text { (recommended) level, dynamics of the } \\
\text { most of them is positive }\end{array}$ & $\begin{array}{c}\text { it is impossible to do } \\
\text { unmistakable } \\
\text { conclusion }\end{array}$ \\
\hline $\begin{array}{c}\text { PJSC } \\
\text { "PBTF" }\end{array}$ & $\begin{array}{c}\text { Financial condition was } \\
\text { unsustainable }\end{array}$ & $\begin{array}{c}\text { The most of coefficients had a positive } \\
\text { trend but they did not reach the } \\
\text { generally accepted recommended level }\end{array}$ & $\begin{array}{c}\text { it is impossible to do } \\
\text { unmistakable } \\
\text { conclusion }\end{array}$ \\
\hline
\end{tabular}


The data in table 2 allow us to make the following conclusions: financial stability has a positive trend in most organizations and it generally corresponds to the main trends in the development of the fisheries industry; there are contradictions in the assessment of financial stability by various methods; method of coefficient calculation is suitable to the greatest extent for the assessment of financial stability when using ratio analysis, the tempo and direction of changing the separate indicators may be different; recommended values of financial coefficients are generalized and does not take into account the specific character of the industry and thus may not reflect the real situation.

Consequently, there is a need to develop such methods of financial stability assessment, which could resolve the identified contradictions and problems. According to the authors, the most consistent with the requirements of the criteria of financial sustainability is an integrated indicator, based on the comparison of the values of a specific set of indicators with the recommended industry-specific values (formula 1):

$$
I=\left(\sum_{i=1}^{n} \frac{P_{i 1}}{P_{i 0}}\right) / n,
$$

Where: $\mathrm{P}_{\mathrm{i} 1}$ - the value of the i-indicator for the given company; $\mathrm{P}_{\mathrm{i} 0}-$ recommended value of $\mathrm{i}-$ indicator for fisheries complex; $\mathrm{n}$ - number of indicators.

This indicator can be used to assess the financial sustainability of the entity of the fisheries industry in accordance with the following rating parameters [12]: above 1,5 absolutely stable (excellent) financial condition; 1,0-1,5 - relatively stable (good) financial condition; $0,5-1,0$ - relatively unstable (satisfactory) financial condition; below 0,5 is absolutely unstable (poor) financial state.

On the basis of the assessment of closeness of correlation between the various indicators of financial stability and the gross profit of organization, the structure of the integrated-rate was determined: the autonomy ratio, financial leverage, flexibility ratio, coefficient of coverage by own floating funds, ratio of financing, ratio of financial stability, day-to-day liquidity ratio and quick ratio. A comparison of indicators is proposed to implement together with those, which are recommended for agriculture, as fishing industry (including fishing, aquaculture and fish processing) is referred to this industry.

The results of the evaluation of financial stability of the studied fishery companies of the Primorsky region (using the integrated indicator) are presented in table 3.

Table 3 - Assessment of the level of financial stability of the fishery companies of the Primorsky region (using the integrated indicator)

\begin{tabular}{|c|c|c|c|}
\hline Company & 2014 & 2015 & 2016 \\
\hline $\begin{array}{c}\text { PJSC } \\
\text { "Dalryba" }\end{array}$ & $\begin{array}{c}-4,02 \\
\text { Absolutely unstable financial } \\
\text { state }\end{array}$ & $\begin{array}{c}2,19 \\
\text { Absolutely stable financial } \\
\text { state }\end{array}$ & $\begin{array}{c}\text { Absolutely stable financial } \\
\text { state }\end{array}$ \\
\hline $\begin{array}{c}1,75 \\
\text { PJSC }\end{array}$ & $\begin{array}{c}1,73 \\
2,13\end{array}$ \\
"NBAMR" & $\begin{array}{c}\text { Absolutely stable financial } \\
\text { state }\end{array}$ & $\begin{array}{c}\text { Absolutely stable financial } \\
\text { state }\end{array}$ & $\begin{array}{c}\text { Absolutely stable financial } \\
\text { state }\end{array}$ \\
\hline PJSC "PBTF" & $\begin{array}{c}-0,72 \\
\text { unstable financial } \\
\text { state }\end{array}$ & $\begin{array}{c}0,83 \\
\text { Relatively unstable financial } \\
\text { state }\end{array}$ & $\begin{array}{c}\text { Relatively stable financial } \\
\text { state }\end{array}$ \\
\hline
\end{tabular}

The results of testing of the proposed method showed that it gives more accurate result, taking into account the specific industry features. Especially clearly the data of JSC "PBTF" demonstrate it (the result is fully consistent with the trends in the financial state of the company), while using the traditional methods, the contradictions were observed. research:

Thus, it is possible to formulate the following conclusions using the results of the

1. The fishing industry is an important sector of the economy of Primorsky Region. To increase the efficiency of its functioning, it is necessary to make complex analysis of the 
achieved results, including the assessment of financial stability of organizations in the industry.

2. The assessment of financial stability must be done taking into account industry features. For this purpose, the using of integrated indicator is the most suitable, as it takes into account the aggregated financial ratios and their comparison with recommended industry values.

3. The use of this method facilitates the solution of problems of analytical substantiation in process of management of financial state of the company and allows to develop a strategy to ensure its financial stability.

\section{REFERENCES}

1. Chipovskaya I.S., Levchenko T.A. The formation of synergies in the operation of the fishery cluster. Ekonomika i predprinimatelstvo. 2015. No. 4-2 (57-2). Pp. 291-296.

2. Danilovskih A.A., Konvisarova E.V. Financial aspects of ensuring the information security of an enterprise. Mezhdunarodnyy studencheskiy nauchnyy vestnik. 2015. No. 4-3. Pp. 398-399.

3. Gilyarovskaya L.T. Analysis and assessment of financial sustainability of commercial organizations. Moscow: Yuniti-Dana, 2012. 159 p.

4. Kovalev V.V., Volkova O.N. Analysis of the economic activity of the enterprise. Moscow: Prospekt, 2014. 239 p.

5. Konvisarova E.V., Neprokin A.V., Konvisarov A.G. The ways of improvement of financial state of small construction company. Vektor nauki Toliattinskogo gosudarstvennogo universiteta. Seriya: Ekonomika i upravleniye. 2016. No. 2 (25). Pp. 22-27.

6. Korneyko O.V., Latkin A.P. Integration of fishery enterprises in the Primorsky region: economic rationales and ways of their realization. Mediterranean Journal of Social Sciences. 2015. T. 6. No. 5 S3. Pp. 118-125.

7. Korneyko O.V., Latkin A.P. Theoretical approaches to management of fishing industry development. Rybnoye khozyaystvo. 2014. No. 3. Pp. 35-37.

8. Lapusta M.G.. Mazurina T.Yu., Skamay L.G. Finance of organizations (enterprises). Moscow: INFRA-M, 2017. 575 p.

9. Levkina E.V., Vorozhbit O.Yu. Influence of external factors on the efficiency of the fish industry of Primorsky Krai. Mezhdunarodnyy studencheskiy nauchnyy vestnik. 2015. No. 4-3. Pp. 416-419.

10. Levchenko T.A, Chipovskaya I.S. Towards the issue of customs regulation of the Primorsky territory fishing industry. Vestnik Moskovskogo gosudarstvennogo oblastnogo universiteta. Seriya: Ekonomika. 2014. No. 1. Pp. 67-76.

11. General results of the work of the Primorsky Krai fisheries complex for 2014-2016. Access mode: http://www.primorsky.ru/authorities/

12. Saakyan T.G. Development of methodical bases for forecasting financial stability of economic entities. Rostov-na-Donu, 2014. $161 \mathrm{p}$.

13. Sheremet A.D. Analysis and diagnostics of financial and economic activity of the enterprise. Moscow: «IPB - BINFA», 2012. 310 p.

14. Vorozhbit O.Yu., Danilovskikh T.E.. Kuzmicheva I.A. Theoretical and methodological aspects of ensuring competitiveness of fishery activities in the Far East of Russia. Moscow: Kreativnaya ekonomika, 2013. 280 p.

15. Vorozhbit O.Yu., Zhuk A.P., Latkin A.P. Maintenance of competitive management for enterprises of fishery industry in the Far East of Russia in conditions of Russia entrance into WTO. Izvestiya TINRO (Tikhookeanskogo nauchno-issledovatelskogo rybokhozyaystvennogo tsentra). 2013. T. 173. Pp. 293-301.

16. Vorozhbit O.Yu., Terentyeva T.V., Titova N.Yu. Sustainable development of fishing complex in Primorsky krai via formation of territorial-sectoral industrial cluster. Azimut nauchnykh issledovaniy: ekonomika i upravleniye. 2016. T. 5. No. 2 (15). Pp. 53-57. 